\title{
The Mediator Role of Self Concept Clarity on the Relationship Between the Need for Absolute Truth, Problem Solving and Symptoms of Stress in Gay Men
}

\author{
Gay Erkeklerde Mutlak Gerçek İhtiyacı ile Problem Çözme ve Stres Belirtileri \\ Arasındaki İlişkide Benlik Kavramının Netliğinin Aracılık Rolünün \\ Incelenmesi
}

\author{
Gizem AKCAN * \\ Erdinç ÖZTÜRK **
}

\begin{abstract}
The self concept is a basic reference point for all people and it is closely related to need for absolute truth. During the formation of awareness of sexual orientation, gay individuals want to capture absolute information about their self concept; therefore, they have high level of need for absolute truth. It has been observed that gay men with low level of self-concept clarity use non-functional problem-solving methods and they show symptoms of intense stress because of their sexual orientation. The main aim of this study is to investigate the mediator role of self-concept clarity on the relationship between the need for absolute truth, problem solving and symptoms of stress in gay men. The participants of the present study consisted of 200 gay men aged between 20 and 50 years old. Demographic Information Form, SelfConcept Clarity Scale, Need for Absolute Truth Scale, Stress Self-Assessment Checklist and ProblemSolving Inventory were applied to the participants. According to the findings of this study, the relationship between need for absolute truth, problem solving, and symptoms of stress was mediated by self-concept clarity in gay men.
\end{abstract}

Keywords: Self-concept Clarity, Need for Absolute Truth, Problem Solving, Symptoms of Stress, Gay Men

Öz: Benlik kavramı bütün insanlar için temel bir referans merkezidir ve mutlak gerçek ihtiyacı ile yakından ilişkilidir. Cinsel yönelim farkındalığı oluşumu sırasında eşcinsel bireyler, benlik kavramları hakkında mutlak bilgi edinmek isterler ve bu nedenle mutlak gerçek ihtiyaçları yüksektir. Benlik kavramının netliği düşük olan gey erkeklerin fonksiyonel olmayan problem çözme yöntemleri kullandıkları ve cinsel yönelimleri nedeniyle yoğun stres belirtileri gösterdikleri gözlenmektedir. Bu çalışmanın amacı, gey erkeklerde mutlak gerçek ihtiyacı, problem çözme ve stres belirtileri arasındaki ilişkide benlik kavramı netliğinin aracılık rolünü araştırmaktır. Bu araştırmanın katılımcıları, 20-50 yaş arası 200 gey erkekten oluşmaktadır. Katılımcılara Demografik Bilgi Formu, Benlik Kavramının Netliği Ölçeği, Mutlak Gerçek İhtiyacı Ölçeği, Stres Belirtileri Ölçeği ve Problem Çözme Envanteri uygulanmıştır. Bu çalışmanın bulgularına göre, gey erkeklerde mutlak gerçek ihtiyacı, problem çözme ve stres belirtileri arasındaki ilişkiye benlik kavramının netliği aracılık etmektedir.

Anahtar sözcükler: Benlik Kavramının Netliği, Mutlak Gerçek İhtiyacı, Problem Çözme, Stres Belirtileri, Gey Erkekler

* Dr. Öğr. Ü., Bartın Üniversitesi, Edebiyat Fakültesi, Psikoloji Bölümü, Bartın. gakcan@bartin.edu.tr, https://orcid.org/0000-0003-1997-9178

** Prof. Dr. İstanbul Üniversitesi - Cerrahpaşa, Adli Tıp ve Adli Bilimler Enstitüsü, Sosyal Bilimler Anabilim Dalı, İstanbul, erdincerdinc@hotmail.com, https://orcid.org/0000-0003-1553-2619 
Sexual orientation was defined as a component of identity that includes a person's sexual and emotional attraction to another person and the behavior and/or social affiliation that may result from this attraction (APA 2015a). A person may be attracted to men, women, both, neither, or to people who are gender queer, androgynous, or have other gender identities (APA \& NASP 2015) Individuals may be identified as lesbian, gay, heterosexual, bisexual, queer, pansexual, or asexual, among others (APA 2012).

Adolescence can be defined as a period of experimentation and individuals begin to develop autonomy during this period. Many youths may question their sexual feelings and becoming aware of sexual feelings is a normal developmental task of adolescence. If adolescents notice that they have same-sex feelings or experiences, they get confused about their sexual orientation Kaufman 2008). This confusion appears to decline over time, with different outcomes for different individuals (Ojanen 2015). However, LGBTI people face additional challenges to their psychological well-being because of the negative consequences of discrimination based on sexual orientation (Herek, Gillis, \& Cogan 2009; Poteat et al. 2009; Ryan et al. 2009; Szymanski \& Gupta 2009; Moradi et al. 2010; Russell et al. 2011). Moreover, they are confronted with isolation and mocking resulting in denial of their actual sexual orientation during the first stages of identity development (identity confusion and comparison stages). So, it leads to identity confusion (Cass 1979). Researcher proposed that individuals sometimes try to discover this aspect of themselves instead of rejecting their sexual orientation. On the one hand, sexual minorities resist in order not to lose the approval of their family, while at the same time they are stucked between the outside world and their internal thoughts, feelings, sexual desires and fantasies. That's why, they experience sexual identity confusion leading to decreases in selfconcept clarity (SCC) (Page, Lindahl \& Malik 2013).

\section{Self-Concept Clarity (SCC)}

Self-concept clarity (SCC) refers to the extent to which self-beliefs are clearly and confidently defined, internally consistent and stable (Campbell, et.al. 1996). Researchers supported that individuals with high self-concept clarity have more psychological well-being; however, individuals with low self-concept clarity have higher-level depression and neuroticism. Other researchers also suggested that low self-concept clarity has a negative impact on many issues, such as using passive coping mechanisms in problem solving (Smith, Wethington \& Zhan 1996; Feinstein, Davila \& Yoneda 2012; Reyes et al. 2015; Hossain \& Ferreira 2019).

In addition, uncertainties about the person's identity are generally associated with strong emotions (Bar-Anan, Wilson \& Gilbert 2009) and psychological incongruency (Luyckx et al. 2008). It is known that identity exploration causes psychological stress during sexual identity development (Berman, Montgomery \& Kurtines 2004). In this context, it is argued that children and adults who have uncertainty about their sexual orientation have more depressive symptoms and suicidal thoughts and low self-esteem than their peers, who call themselves heterosexual (Poteat et al. 2009).

Cass (1979) supported that sexual minorities have low self-concept clarity during the first stages of identity development. Coming out is often an important psychological step for them (Coleman 1982). Research has shown that feeling positively about one's sexual orientation and integrating it into one's life fosters greater well-being and mental health. This integration often involves disclosing one's identity to others; it may also entail participating in the gay community (Rosario, Schrimshaw \& Hunter 2004). Ertan (2009) stated that coming out refers to the construction of sexual orientation as gay men and becoming visible in social life. According to him, 'coming out' is the end of the identity exploration. It is seen that individuals define their own selves and accept themselves with 'coming out' process. Plummer (1995) supported that 
when individuals complete 'coming out' process, their perceptions about who they really are become clear. However, coming out in new social and professional occasions can be highly stressful for some gay men and lead to anxiety. Accordingly, it can be said that coming out process is both important and stressful for gay men to clarify their self-concept.

\section{Need For Absolute Truth (NAT)}

It is seen that individuals want to obtain absolute knowledge about their self during identity development. According to Şimşek (2013), people have high propensity to engage in abstract self-analysis aimed at capturing absolute knowledge about the self. He calls this motive "the need for absolute truth" (NAT). NAT refers to one of the highest-level representations concerning the self: the truth beyond the self or personal experiences, a truth that is overgeneralized, superordinate and valid in all contexts. The author argued that this process leads to frustrations and internal conflicts because of the infinite number of possible relationships related to the absolute truth. It is seen that NAT is positively associated with psychopathology and negatively associated with mental health. In the study conducted by Campbell et al. (1996), it was found that there was a negative relationship between self-focus and self-concept clarity. In support of this information, Şimşek (2013) found that NAT was correlated positively with mental health problems, such as anxiety and depression, and negatively with positive mental health indicators, such as self-esteem, self-concept clarity, and insight.

It can be considered that people who want to obtain absolute truth about themselves experience intolerance to uncertainty. Because, people with high-level NAT want to have valid, clear, and absolute knowledge about themselves in every situation. Therefore, there is a positive relationship between NAT and intolerance to uncertainty (Akcan, 2013; Şimşek, Ceylandag \& Akcan 2013). People who are unable to tolerate uncertainty feel uncomfortable and make more efforts to reduce uncertainty (Buhr \& Dugas 2002; Leite \& Kuiper 2008). For example; they seek more information to reduce the uncertainty of their decisions or avoid uncertain situations. In addition, Leite \& Kuiper (2008) supported that high-level intolerance to uncertainty is associated with high-level depression, anxiety, stress, sadness, lower processing speed in uncertain situations requiring problem solving ability.

Watkins (2008) indicated that self-focus is detrimental for mental health if it consists of abstract construal of events and actions. By abstractness, Watkins means general, superordinate and decontextualized evaluations of psychological experiences. Such representations are considered to refer to the essence and meaning of self-relevant events and actions. In contrast, low level representations (focusing on "how") that are concrete, contextual and sub-ordinate are more constructive, and therefore make a contribution to mental health. The negative consequences of the high-level representations indicated by Watkins (2008) can also be applied to the NAT. According to Nisbet and Wilson (1977), focusing on high-level representations increases the tendency of individuals to approach different situations with general theories or common accounts, and reduces insight which is negatively related with self-esteem and selfconcept clarity. Since each event has its own dynamics, approaching the events with general theories may not be functional.

Troiden (1989) found that gay men do not have clear self-concept and experience identity confusion during the first stages of sexual identity development. Moreover, according to him, they can accept that their feelings and behaviours are related to the experience of being a gay man and they try to find more information about their self-concept via different sources to handle with identity confusion and have clear self-concept. Butzer and Kuiper (2006) stated that individuals who are uncertain about their self-concept have more tendency to find absolute truths about themselves because of intolerance to uncertainty. It can be said that gay men with 
low self concept clarity have high-level NAT in order to accept their identity and develop healthy self-concept in the process of identity development.

Furthermore, Wegner and Lane (1995) also supported that in coming out process attempts at secrecy activate a set of cognitive processes that lead to an obsessive preoccupation with the secret. Coming out negates the need for concealment and therefore helps the person avoid the secrecy cycle. It can be said that in the coming out stage of sexual identity development, sexual minorities have high- level NAT. It can be said that especially in the coming process, gay men have high- level NAT. It can be suggested that gay men want to capture absolute and clear knowledge about their self-concept during identity development (coming out). It is hypothesized that when gay men try to find truths that are overgeneralized, superordinate and valid in all contexts about themselves, they experience self-confusion because of discrepancies between the current and ideal self-representations. That's why, their self-concept clarity decreases. Therefore, it can be said that gay men with high-level NAT have low self-concept clarity. It is clear that both high-level NAT leads to low self-concept clarity, and low self-concept clarity leads to high-level NAT.

\section{The Mediator Role of SCC on the Relationship Between NAT, Problem Solving and Symptoms of Stress}

Watkins (2008) stated that abstract and highest-level representations have three main negative effects on mental health, such as problem-solving ability, self-regulation and development of depression. Şimşek (2013) also suggested that these three main negative effects of highest-level representations can be applied to NAT which is one of the highest-level representations concerning the self: the truth beyond the self or personal experiences, a truth that is overgeneralized, superordinate and valid in all contexts. First, a higher- level NAT would increase the tendency to over-generalize, since the basic aim is to find general, superordinate, and decontextualized rules for behaviour or meaning. It would also be more difficult for those who have higher levels of NAT to self-regulate because, as Watkins indicated, self-regulation benefits from concrete thinking and focusing on the immediate demands of the present situation. Finally, and most importantly, in every instant of self-reflection, a higher-level NAT would obstruct problem solving on interpersonal and intrapersonal levels, through the counterproductive need to find a fundamental explanation or "meaning" for each specific situation.

In parallel, Watkins and Teasdale (2004) mentioned that focusing less analytically on one's own experiences is more beneficial for mental health than focusing abstractly on meanings and causes. In addition, Watkins (2008) noted that focusing on self is detrimental for mental health if it includes abstract representations related to events and actions. In this context, it can be said that NAT has negative impact on mental health since it involves abstract thinking to find the truth about behaviours and meanings. Akcan (2013) also supported that people who engage in self-focus are often confronted with difficulties in problem solving and in coping with stress as a direct result of the NAT related to pathology. It can be thought that NAT is positively correlated with symptoms of stress and negatively correlated with problem solving skills.

It is argued that self-concept clarity is negatively correlated with the factors that cause psychological stress such as anxiety, negative mood and rumination (Slotter, Gardner \& Finkel 2010). In addition, in the study organized by Ritchie et al. (2011), it is seen that self-concept clarity affects psychological functioning at the optimum level by enabling individuals to determine the relationship between source of stress and self-concept. Ed, Suh, Lucas and Smith (1999) also supported that there is a negative relationship between stress and self-concept clarity.

It is reported that self-concept clarity acts as a protective task against stress-generating events because individuals with a clear self-concept are less affected by stressful events and are 
more successful in dealing with negative judgments (Lee-Flynn et al. 2011). For example; individuals who have clear beliefs about themselves guide themselves through the decisionmaking process, receive feedback about their beliefs, and are more resistant to change their beliefs (Swann, Pelham \& Chidester 1988). However, it is noteworthy that individuals with low self-concept clarity react more to stressful events because their views on themselves do not give them effective and consistent information about how to behave (Kernis, Paradis Whitaker, Wheatman \& Goldman 2000). In parallel with the studies, Constantino, Wilson, Horowitz and Pinel (2006) stated that self-concept clarity acts as a buffer in the stress process. In addition, low self-concept clarity has negative effects on many issues such as using passive coping mechanisms against problems (Bechtoldt et al. 2010).

Besides, it is argued that people who have low self-concept clarity have more difficulties to define and understand their problematic thoughts, emotions and behaviours (Leite \& Kuiper 2008). According to Leite and Kuiper (2008) such individuals have more rumination to raise their awareness and insight before taking action. However, it is seen that the individuals with high self-concept clarity understand the problems related to their behaviours, thoughts and emotions more clearly. Moreover, people with low level self-concept clarity are uncertain about their characteristics and abilities. So, they have low level of hope to find and apply appropriate solutions when they face with difficulties. Prochaska and DiClemente (1983) also stated that individuals with low self-concept clarity are not clear on their behaviours, thoughts, emotions, roles in their relationships and environments.

According to Troiden (1989), gay men experience identity confusion in the first stages of identity development and so, they try to find more clear and absolute knowledge about their self-concept via different sources to handle with this situation. Gay men who want to obtain general, valid and accurate knowledge about their self during self-discovery may be considered to have high-level NAT. It can be thought that gay men who focus excessively on themselves due to NAT may experience contradictions about their self and so, their self-concept clarity will decrease since the information they acquire differs according to circumstances. Thus, they will perceive more differences between the identity they have and the identity they want to be. It can be thought that when the level of NAT increases, the level of self-concept clarity decreases.

It was supported that self-concept clarity is negatively correlated with the indices of psychological distress like anxiety, negative affect, rumination and is positively correlated with subjective well-being (De Cremer \& Sedikides 2005; Slotter, Gardner \& Finkel 2010). Besides, because of negative attitudes of the society towards gay men, they experience excessive stress use non-functional problem-solving strategies (Campbell et al. 1996; Campbell, Assanand \& Di Paula 2003). Meyer and Frost (2013) also stated that minority stress is based on the premise that (a) prejudice and stigma directed toward LGBT people bring about unique stressors and (b) these stressors cause adverse health outcomes including mental and physical disorders. Cass (1979) also found that gay men have low self-concept clarity and they often have trouble in accepting their sexual orientation as the part of their self-concept and as a result, they show further symptoms of stress. In this sense, it is seen that self-concept of clarity is negatively correlated with symptoms of stress and positively correlated with problem solving skills.

During the identity exploration, because of high-level NAT, gay men have low self-concept clarity and this situation has adverse effects on their psychological well-being and leads to an increase in symptoms of stress and difficulties in problem solving. However, if people with high-level NAT have high self concept clarity, they can be more successful in problem solving and coping with stress. Thus, it can be calimed that if the effect of self-concept clarity on the relationship between NAT, problem solving and symptoms of stress is eliminated, there will be decrease in the relationship between NAT, problem solving and symptoms of stress. In 
summary, it is thought that NAT affects symptoms of stress and problem-solving skills due to the effect of self-concept clarity. The aim of this study is to investigate the mediator role of selfconcept clarity on the relationship between NAT, problem solving and symptoms of stress in gay men.

\section{Method}

\section{Participants and Procedure}

The participants of the present study consisted of 200 gay men studied at the level of high school and bachelor's degree, selected from the members of Turkey LGBTI (Lesbian, Gay, Bisexual, Trans, Intersex) Association Kaos GL, Pink Life LGBTI+ Association, Lambda Istanbul LGBTI Association. The participants were between 20 and 50 years old. Snowball sampling procedure was employed to select the participants and the voluntary nature of the participation was clearly explained to the participants prior to distributing the scale. This study was approved by the Istanbul Arel University Ethics Committee (approval no. 2016/04, date 25/05/2016). All participants were provided with the written informed consent prior to participate in the study.

In this study, the scales were applied to the participants by using the paper-pencil method, by inviting the participants to private consultancy centers in Istanbul. In addition, the data were obtained from the participants via the online survey method created by the researcher in the internet.

\section{Measures}

\section{Demographic Information Form}

The Demographic Information Form was developed by the researchers to get information about age, education level and gender of participants and it consists of 13 items.

\section{Self-Concept Clarity Scale (SCCS)}

The Self-Concept Clarity Scale (SCCS) was developed by Campbell and colleagues (1996) to measure the extent to which beliefs about self-concept are based on clear and precise information and how reliably the self-concept is defined. The scale consists of 12 items such as "My beliefs about myself often conflict with one another," "I spend a lot of time wondering about what kind of person I really am," and "When I think about the kind of person I have been in the past, I'm not sure what I was really like." The response format of the SCCS is a 5-point Likert scale anchored by $1=$ strongly disagree to $5=$ strongly agree. Thus, higher scores indicate a more consistent and stable self-conceptThe Cronbach's alpha reliability coefficient of the scale was found to be .86 . The scale was adapted to Turkish by Sumer and Gungor (1999). The Cronbach's alpha reliability coefficient of the scale was found to be $\alpha=.89$ in the study. In the present study, the Cronbach's alpha reliability coefficient was found to be.84.

\section{Need for Absolute Truth Scale -NATS}

The NAT Scale was developed by Şimşek (2013) in order to measure the degree to which participants have a tendency to seek absolute self-knowledge. Through a series of three studies, Şimşek developed and validated the NAT Scale, finding an internal consistency of .75. He reported sufficient test-retest reliability $(\mathrm{r}=.72)$. In the third study, he also showed the suppressor effect of the NAT on selfreflection by using different mental health variables, such as self-concept clarity, self-esteem, depression, and anxiety. The NAT scale response format is a 5 -point Likert scale, anchored by $1=$ strongly disagree to $5=$ strongly agree. Higher scores reflect a greater NAT. The scale consisted of five items ("I always try to find 'the facts' about 
me," "I think that the existing and real me are different," "I hope I will find myself as I really am one day," "I always think about 'the facts' about me," "I try to understand what my experiences actually mean"). Internal consistency was found to be $\alpha=.79$ in the present study.

\section{Stress Self-Assessment Checklist- (SAC)}

Stress Self-Assessment Checklist (SAC) was developed by Das Gupta (1992) to identify the symptoms related to stress in humans. Hovardaoglu (1997) adapted the scale to Turkish and it consists of three components as the cognitive-affective, physiological and pain-complaint component. Split half test Cronbach's $\alpha$ value for each subscale was between .62 and.73. It is a Likert-type scale with the Turkish form consisting of 38 items evaluating the symptoms of stress with each of the items in the symptoms list having a 4-grade scoring. An increase in the score represents an increased frequency of the symptoms. For this study, the Cronbach's $\alpha$ value of the scale was calculated as 0.92 . The Alpha coefficient for the cognitive-affective subscale was found to be $0.74,0.82$ for physiological subscale and 0.82 for pain-complaint in the present study.

\section{Problem Solving Inventory (PSI)}

The PSI was developed by Heppner and Petersen (1982) to assess perception of one's problem solving ability as well as behaviours and attitudes associated with problem solving style. It was adapted into Turkish by Şahin et al. (1993). The PSI consists of 35 items, including 3 filler items $(9,22,29)$ with a 6 -point Likert type scale $(1=$ strongly agree, $6=$ strongly disagree). The total score range is between 32 to 192. Heppner and Petersen (1982) suggested that PSI scores should not be viewed as measures of actual problem-solving ability, only as perceived problemsolving. Higher scores indicate negative perceptions of one's problem-solving ability. In the reliability and validity study conducted with university students, Şahin et al. (1993) calculated the internal consistency of the scale to be ".88". The high score obtained from the scale indicates that the individual perceives oneself insufficient in the skills of problem solving. Cronbach's $\alpha$ value of the scale was calculated as .89 in this study. After the factor analysis; it was found that the scale has 6 factors including "impatient approach" $(\alpha=.78)$, "thinking approach" ( $\alpha=.76)$, "avoidant approach" ( $\alpha=.74)$, "evaluator approach" ( $\alpha=.69)$, "self-trusted approach" $(\alpha=.64)$, and "planful approach" $(\alpha=.59)$. In the current study the Cronbach's $\alpha$ reliability factor for impatient approach subscale was calculated to be $.74, .59$ for thinking approach subscale, .68 for avoidant approach subscale, .66 for evaluator approach subscale, .82 for self-trusted approach subscale and .51 for planful approach subscale.

\section{Analyses}

In this study, SPSS (Statistical Package for Social Sciences) for Windows 22.0 program was utilized to analyse the findings of Demographic Information Form. Moreover, Lisrel 8.80 program was used for Confirmatory Factor Analysis and Structural Equation Modelling. As a first step, the measurement model was tested as the necessity of phased approach. Then, the relationship between self-concept clarity, problem solving and symptoms of stress, the relationship between the need for absolute truth (NAT) and self-concept clarity, the relationship between NAT and problem solving and symptoms of stress were assessed. Moreover, the mediator role of self-concept clarity on the relationship between the need for absolute truth, problem solving and symptoms of stress in gay men was investigated in this study. 


\section{Results}

\section{Testing Measurement Model}

Four latent variables were used in the structural equation model testing: NATS, SCCS, SAC and PSI. NATS is an one dimensional scale witf 5 items; SCCS is an one dimensional scale with 12 items; SAC has three subdimensions and 37 items, and PSI has six subdimensions and 35 items. The kurtosis and skewness values of all scales and subscales are normally distributed since the values are between -2 and +2 (George \& Mallery 2010). The findings of this study indicated that self-concept clarity scores were weakly and negatively correlated with problem solving, but moderately and negatively correlated with symptoms of stress and NAT. NAT scores were weakly and positively correlated with symptoms of stress and problem solving. In addition to this, it can be observed that the correlations between all latent variables in the model were all

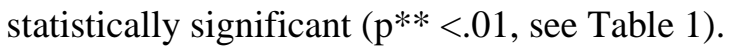

Table 1. Factor Loadings, $\mathrm{t}$-Values and Intercorrelations of the Latent Variables for the Measurement Model

\begin{tabular}{lllcrc}
\hline & Path & & Standardized Factor Loading & t-value & $\mathrm{R}^{2}$ \\
\hline SCCS & $\longrightarrow$ & PSE & -.59 & $-10.88^{* *}$ & .34 \\
SCCS & $\longrightarrow$ & SAC & -.60 & $-11.57 * *$ & .36 \\
NATS & $\longrightarrow$ & PSE & .39 & $5.67 * *$ & .15 \\
NATS & $\longrightarrow$ & SAC & .44 & $6.84 * *$ & .19 \\
NATS & $\longrightarrow$ & SCCS & -.69 & $-13.80 * *$ & 0.44
\end{tabular}

Note: SCCS: Self Concept Clarity Scale, NATS: Need for Absolute Truth Scale; PSE: Problem Solving Inventory; SAC: Stress Self-Assessment Checklist

The measurement model that was created with the original factor loadings of the scales did not have acceptable model fit indices, $\chi^{2} / \mathrm{df}=3.34$; GFI $=.73$; CFI $=.88 ; \mathrm{IFI}=.88$; SRMR $=.09$; RMSEA =.10 ( $\chi 2 / \mathrm{df}<5 ;$ RMSEA>.08; CFI<.90; IFI<.90; GFI<.90; SRMR>.08) (see. Table 2.).

Table 2. Results of the Confirmatory Factor Analyses on the Scores of the Measurement Model That was Created with the Original Factor Loadings of the Scales

\begin{tabular}{lcccccc}
\hline Model & $\chi^{2} / \mathrm{df}$ & RMSEA & CFI & IFI & GFI & SRMR \\
\hline $\begin{array}{l}\text { Measurement } \\
\text { Model }\end{array}$ & 3.34 & .10 & .88 & .88 & .73 & .09 \\
\hline
\end{tabular}

Note: $\mathrm{N}=200 ; \chi^{2}=\mathrm{Ki}$ square; $\mathrm{df}=$ degrees of freedom; RMSEA = root-mean-square error of approximation; GFI = goodness-of-fit index; CFI = comparative fit-index; SRMR = standardized root-mean-square residual; IFI = incremental fit index

The measurement model which was created with the original factor loadings of the scales resulted in a bad fit to the data. Thus, the measurement model was recreated by parcelling each latent constructs in this study. Item parcelling methodology normalises the distribution of observed variables and increases the reliability of these indicators. In order to create parcels that would function as indicators of the latent variables, items were ranked according to the size of the item-total correlation, and sets of items were summed. We chose to create multiple indicators with the aim of increasing the reliability of the latent variables. Three parcels for SCCS, two parcels for NATS, three parcels for SAC, and three parcels for PSI were used based on a simple thumb rule: the more the items, the greater the number of parcels (Kishton \& Widaman 1994; MacCallum \& Austin 2000).

Goodness of fit statistics for the parcelled measurement model were better than the 
measurement model with the original factor loadings A comparison of the goodness of fit statistics with the results of the measurement model yielded a good fit to the data as shown in Table 2, $\chi^{2} / \mathrm{df}=2.71 ; \mathrm{GFI}=.91 ; \mathrm{CFI}=.97 ; \mathrm{IFI}=.97 ; \mathrm{SRMR}=.05 ; \mathrm{RMSEA}=.09\left(\chi^{2} / \mathrm{df}<5\right.$; RMSEA $>.08 ; \mathrm{CFI}>.95 ; \mathrm{IFI}>.95 ; \mathrm{GFI}>.90 ;$ SRMR $\leq .05$ ) (see .Table 3.).

Table. 3 Results of the Confirmatory Factor Analyses on the Scores of the Measurement Model That was Parcelled

\begin{tabular}{lllllll}
\hline Model & $\chi^{2} / \mathrm{df}$ & RMSEA & CFI & IFI & GFI & SRMR \\
\hline $\begin{array}{l}\text { Measurement } \\
\text { Model }\end{array}$ & 2.71 & .09 & .97 & .97 & .91 & .05 \\
\hline
\end{tabular}

Note: $\mathrm{N}=200 ; \chi^{2}=\mathrm{Ki}$ square; $\mathrm{df}=$ degrees of freedom; RMSEA = root-mean-square error of approximation; GFI = goodness-of-fit index; CFI = comparative fit-index; SRMR = standardized root-mean-square residual; IFI = incremental fit index

Figure 1 summarizes the full number of hypothesized relations between the latent variables.

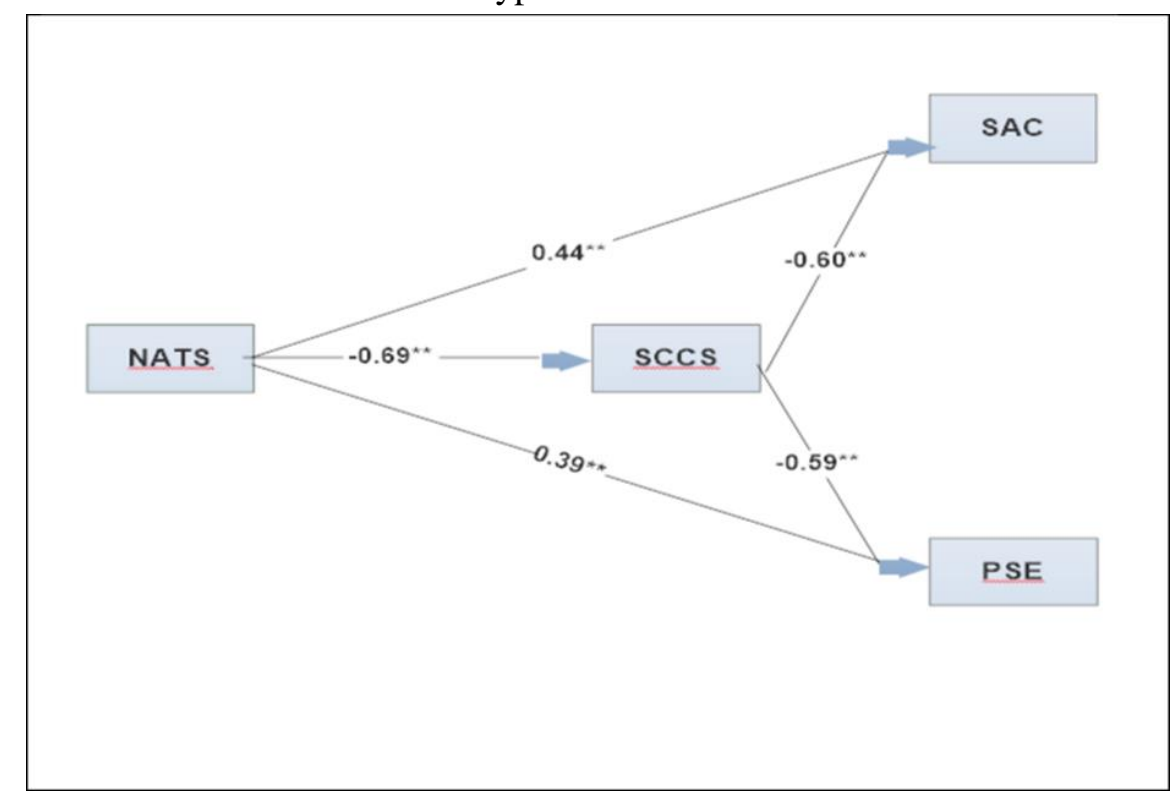

Fig. 1 Standardized parameter estimates of the measurement model

Note: $\mathrm{p}^{*<.05} ; \mathrm{p}^{* *<.01}$; Note: SCCS: Self Concept Clarity Scale, NATS: Need for Absolute Truth Scale; PSE: Problem Solving Inventory; SAC: Stress Self-Assessment Checklist

\section{Testing Structural Model}

The aim of the structural model was to test whether NAT predicts PSI and SAC in gay men via the mediator effect of SCCS. Table 4. presents an overview of the results produced by the structural model. Accordingly, the effect of NAT on SAC and PSI was not statistically significant. Omitting the paths created by these relationships may contribute to the improvement of the model. 
Table 4. Factor Loadings, t-Values and Intercorrelations of Latent Variables for the Structural Model

\begin{tabular}{lllccc}
\hline & Path & & Standardized Factor Loading & t-value & $\mathrm{R}^{2}$ \\
\hline $\mathrm{SCCS}$ & $\longrightarrow$ & PSE & -0.64 & $-5.80^{* *}$ & .40 \\
$\mathrm{SCCS}$ & $\longrightarrow$ & -.58 & $-5.64 * *$ & .33 \\
NATS & SAC & -.06 & -.55 & .003 \\
NATS & $\longrightarrow$ & PSE & .03 & .33 & .000 \\
NATS & $\longrightarrow$ & SAC & -.69 & $-8.39 * *$ & .47
\end{tabular}

Note: SCCS: Self Concept Clarity Scale, NATS: Need for Absolute Truth Scale; PSE: Problem Solving Inventory; SAC: Stress Self-Assessment Checklist

Testing the mediator effect of self-concept clarity on the relationship between NAT, PSI and SAC resulted in the following goodness of fit statistics: $\chi^{2 /} \mathrm{df}=2.69 ; \mathrm{GFI}=.91 ; \mathrm{CFI}=.97$; IFI= $.97 ; \mathrm{SRMR}=.05 ; \mathrm{RMSEA}=.09\left(\chi^{2} / \mathrm{df}<5 ;\right.$ RMSEA $>.08 ;$ CFI $>.95 ;$ IFI $>.95 ;$ GFI $>.90$;

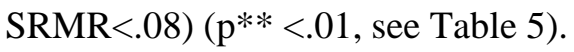

Table 5. Results of the Goodness of Fit Statistics of the Structural Model

\begin{tabular}{lcccccc}
\hline Model & $\chi^{2} / \mathrm{df}$ & RMSEA & CFI & IFI & GFI & SRMR \\
\hline $\begin{array}{l}\text { Measurement } \\
\text { Model }\end{array}$ & 2.69 & .09 & .97 & .97 & .91 & .05 \\
\hline
\end{tabular}

Note: $\mathrm{N}=200 ; \chi^{2}=\mathrm{Ki}$ square; $\mathrm{df}=$ degrees of freedom; RMSEA = root-mean-square error of approximation; GFI = goodness-of-fit index; CFI = comparative fit-index; SRMR = standardized root-mean-square residual; IFI = incremental fit index

Standardized parameter estimates of the structural model are represented in Figure 2.

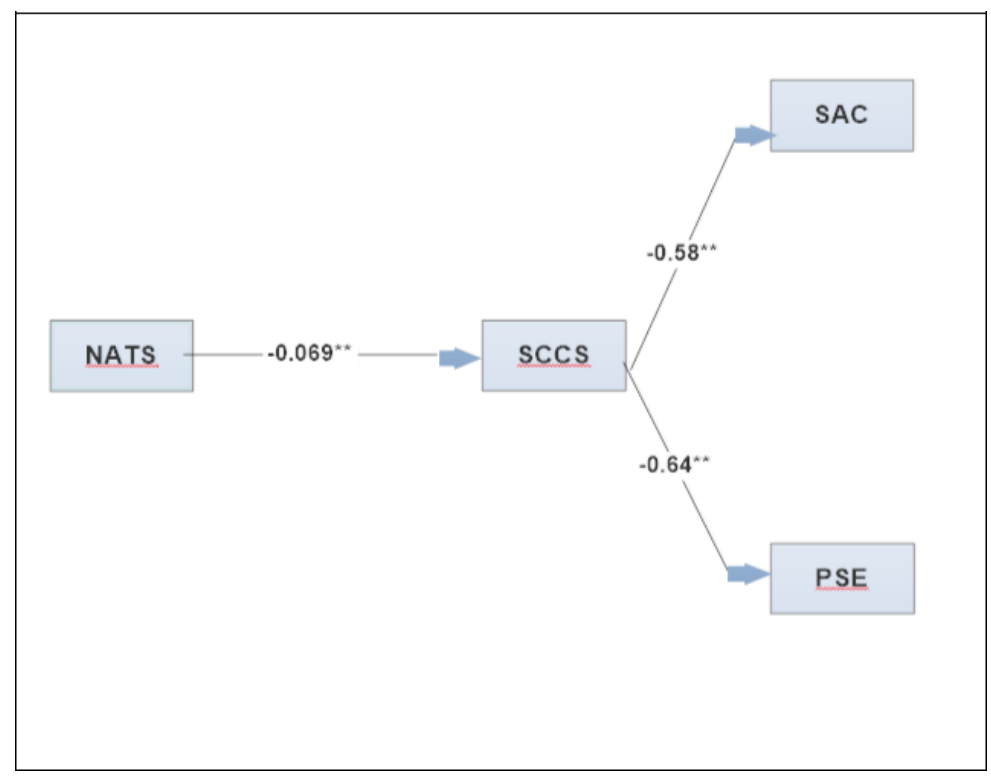

Fig. 2. Standardized Parameter Estimates of the Structural Model

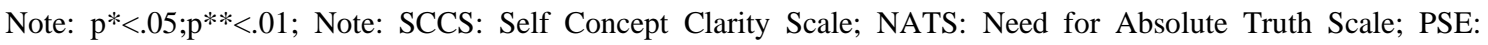
Problem Solving Inventory; SAC: Stress Self-Assessment Checklist

Testing the mediator role of SCCS with respect to SAC in the following goodness of fit statistics: $\chi^{2} / \mathrm{df}=2.61 ; \mathrm{GFI}=.91 ; \mathrm{CFI}=.97 ; \mathrm{IFI}=.97 ; \mathrm{SRMR}=.050 ; \mathrm{RMSEA}=.09\left(\chi^{2} / \mathrm{df}<5\right.$; RMSEA $>.08 ; \mathrm{CFI}>.95 ; \mathrm{IFI}>.95 ; \mathrm{GFI}>.90 ; \mathrm{SRMR} \leq .05$ ) (see Table 6 ). Chi-square difference test statistic $(.38<3.84, \mathrm{p}>.05)$ indicated that there was no significant difference between these models. The path from NATS to SAC was not necessary for a better fit to the data, and therefore 
it could be omitted from the model.

Table 6. Results of Goodness of Fit Statistics of Structural Model When the Path From NATS to SAC Was Omitted

\begin{tabular}{lllllll}
\hline Model & $\chi^{2} / \mathrm{df}$ & RMSEA & CFI & IFI & GFI & SRMR \\
\hline $\begin{array}{l}\text { Measurement } \\
\text { Model }\end{array}$ & 2.61 & .09 & .97 & .97 & .91 & .05 \\
\hline $\begin{array}{l}\text { Note: } \mathrm{N}=200 ; \\
\text { goodness-of-fit index; }\end{array}$ & & & & \\
incremental fit index
\end{tabular}

Testing the mediator effect of SCCS with respect to PSI resulted in the following goodness of fit statistics: $\chi^{2} / \mathrm{df}=2.55 ; \mathrm{GFI}=.91 ; \mathrm{CFI}=.97 ; \mathrm{IFI}=.97$; SRMR $=.05 ; \mathrm{RMSEA}=.08\left(\chi^{2} / \mathrm{df}<5\right.$; RMSEA>.08; CFI>.95; IFI>.95; GFI>.90; SRMR<.08) (see Table 7). Chi-square difference test statistic $(.31<3.84, \mathrm{p}>.05)$ indicated that there is no difference between these models, showing that the path from NATS to PSI was not necessary for a better fit to the data, and therefore it could be omitted from the model.

Table 7. Results of the Goodness Fit Statistics of the Structural Model When the Path From NATS to PSI Was Omitted

\begin{tabular}{lcccccc}
\hline Model & $\chi^{2} / \mathrm{df}$ & RMSEA & CFI & IFI & GFI & SRMR \\
\hline $\begin{array}{l}\text { Measurement } \\
\text { Model }\end{array}$ & 2.55 & .08 & .97 & .97 & .91 & .05 \\
\hline
\end{tabular}

Note: $\mathrm{N}=200 ; \chi^{2}=\mathrm{Ki}$ square; $\mathrm{df}=$ degrees of freedom; RMSEA = root-mean-square error of approximation; GFI = goodness-of-fit index; CFI = comparative fit-index; SRMR = standardized root-mean-square residual; IFI = incremental fit index

Standardized parameter estimates of the final version of the structural model are represented in Figure 3.

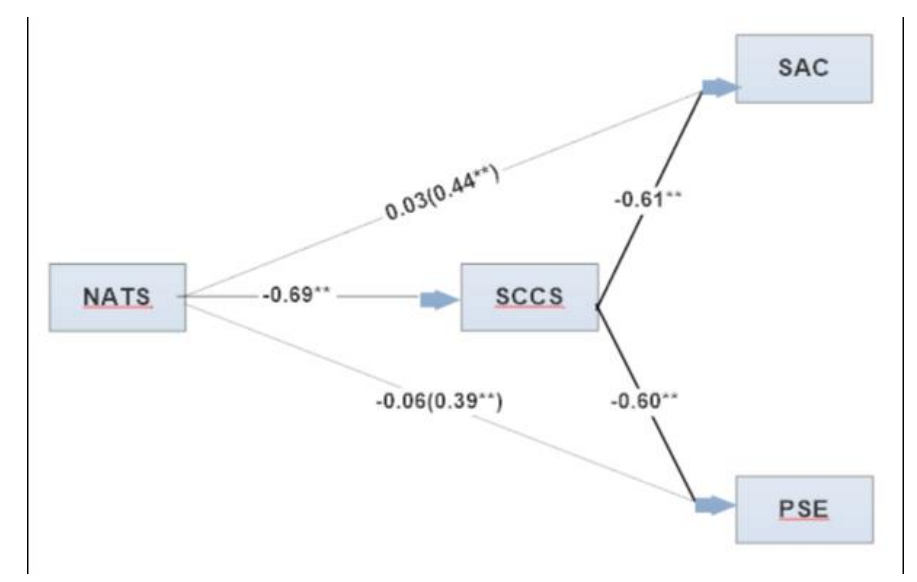

Fig. 3. Standardized Parameter Estimates of the Final Version of the Structural Model

Note: $\mathrm{p}^{*<.05} ; \mathrm{p}^{* *<.01}$; Note: SCCS: Self Concept Clarity Scale; NATS: Need for Absolute Truth Scale; PSE: Problem Solving Inventory; SAC: Stress Self-Assessment Checklist

These results of this study suggested that the relationship between NATS, PSI and SAC was fully mediated by SCCS in gay men.

\section{Discussion}

The purpose of the current study was to examine the effect of NAT on the symptoms of stress and problem solving with the focus on the mediator role of self-concept clarity in gay men. It 
was hypothesized that, gay men with high-level NAT, do not have clear self-concept during the identity exploration process. Thus, gay men suffer from psychological issues such as increase in symptoms of stress and difficulties in problem solving. Thus, in this study, it was supported that if the effect of self-concept clarity on the relationship between NAT, problem solving and symptoms of stress is eliminated, there will be decrease in the relationship between NAT, problem solving and symptoms of stress. The findings were in line with this hypothesis. So, it is clear that self-concept clarity variable fully mediated the relationship between NAT, problem solving and symptoms of stress.

Troiden (1989) supported that gay men want to capture absolute knowledge about selfconcept during identity development and identity exploration. It can be stated that gay men who do not have a general, consistent, and accurate knowledge about their self-concept during identity exploration consequently have high-level NAT. It can be also thought that when gay men with high-level NAT try to capture absolute knowledge about their self-concept, they experience confusion about their self-concept and as a result, their self-concept clarity decrease and they perceive discrepancies between the current and ideal self-representations.

Furthermore, it can be thought that gay men face plenty of problems during their lifespan. According to Öztürk's study (1994; 1998), sexual minority groups facing criticism experience more anxiety above normal standards because of the effect of traditional pattern of Turkish families. Moreover, he also concluded that anxiety levels of gay men who regret their sexual orientation are significantly higher than those of people who do not. Similarly, Newman and Muzzanigra (1993) found that being gay men is less accepted in families with traditional values such as religion, marriage, and having children, and individuals experience more feelings of depression and anxiety such as sensitivity, denial, guilt and shame.

Meyer (2003) argues that in the Minority Stress Model (Minority Stress Model), the hostile attitudes and stressful life events faced by LGBT individuals are expected to be exposed to violence and that these internalized expectations increase the risk of experiencing health problems. According to Uluyol (2016), reactions of families and peers of LGBT individuals during the coming out process affect the level of stress and their relationships with their environment.It can be suggested that experiencing social isolation leads to more severe symptoms of stress in sexual minority groups. Lackner et al. (1993) also supported that gay men experience intense stress and depression; however, they add that social support assumes a protective role against psychological disorders. Furthermore, Cass (1979) suggested that, gay men have severe symptoms of stress because they do not accept their sexual orientation as a part of whole identity, and so they do not have a clear self-concept. In this context, one can claim that people who have clear self-concept accept their sexual orientation as a part of their whole identity and have lower level of stress. Campbell et al. (1996) found that people who have low self-concept clarity show more symptoms of stress and have difficulties in problem solving.

According to the findings of Akcan's study (2013), NAT has two dimensions which are searching for the true self and the causes of one's experiences. Understanding the causes of one's experiences is effective on changing behaviours that affect people negatively and lead to adjustment problems with society. It can be stated that understanding the causes of one's experiences plays an important role on self-regulation and problem solving. Based on this, one can easily conclude that finding the causes of one's experiences will have a positive effect on one's life. Moreover, it is thought that if gay men with high-level NAT have clear self-concept, they can use more functional coping strategies towards problems they experience. On the other hand, one can easily say that low self-concept clarity plays an important role on the increase of symptoms of stress and use of non-functional problem-solving strategies. 
The findings of this study are in parallel with the findings of other studies found in the literature. It is clear that NAT has a positive relationship with symptoms of stress, but it has a negative relationship with self-concept clarity and problem-solving variables. However, low scores in the problem-solving inventory reflect efficacy in problem solving and thus, an increase in NAT will automatically result in an increase in problem solving capabilities. Gay men with high-level NAT have experience higher symptoms of stress because of low self-concept clarity; however, it can be said that if gay men have high self-concept clarity, they will show less symptoms of stress and use more functional problem-solving skills. In this context, it is seen that the relationship between NAT, problem solving, and symptoms of stress was mediated by self-concept clarity in gay men.

The most important limitation of the present research is its correlational nature. Although sophisticated analysis techniques were used, the causal directions among the constructs are only theoretical at present, and should be subjected to further stringent testing, either in an experimental design, or by using longitudinal data. This study was conducted in Istanbul in Turkey with only 200 gay men and the generalizability to other population is limited. Future research should take cultural differences into account in examining the relationships among the variables used in the present model. Finally, only gay men were included yo this study and future researches should investigate the similarities and differences between gay man and lesbian women. 


\section{REFERENCES}

American Psychological Association (APA). (2015a). "Guidelines for psychological practice with transgender and gender nonconforming people”. American Psychologist 70 (2015a) 832-864 doi.org/10.1037/a0039906.

American Psychological Association (APA). (2012). "Guidelines for psychological practice with lesbian, gay, and bisexual clients ”. American Psychologist 67(2012) 10-42. doi:10.1037/a0024659

American Psychological Association \& National Association of School Psychologists. (2015). Resolution on gender and sexual orientation diversity in children and adolescents in schools. Retrieved from: http://www.apa.org/about/policy/orie ntation-diversity.aspx.

Akcan G. (2013). Mutlak Gerçek İhtiyacı Ölçeği Geliştirme Çalışması. Yüksek Lisans Tezi. İstanbul Arel Üniversitesi SBE. İstanbul 2013.

Bar-Anan Y., Wilson T. D. \& Gilbert D. T. (2009). "The feeling of uncertainty intensifies affective reactions". Emotion 9 (2009) 123-127.

Bechtoldt M. N., De Dreu, C. K. W., Nijstad, B. A. \& Zapf, D. (2010). Self-concept clarity and the management of social confict. Journal of Personality 78 (2010) 539-574.

Berman S. L., Montgomery M. J. \& Kurtines W. M. (2004). "The development and validation of a measure of identity distress ". Identity: An International Journal of Theory and Research 4 (2004) 1-8.

Buhr K. \& Dugas M. J. (2002). "The intolerance of uncertainty scale: Psychometric properties of the English version”. Behaviour Research and Therapy 40 (2002) 931-945.

Butzer B. \& Kuiper N. A. (2006). "Relationships between the frequency of social comparisons and selfconcept clarity, intolerance of uncertainty, anxiety, and depression ". Personality and Individual Differences 41 (2006) 167-176.

Campbell J. D., Assanand S. \& Di Paula A. (2003). "The structure of the self concept and its relation to psychological adjustment”. Journal of Personality 71 (2003) 115-140.

Campbell J. D., Trapnell P. D., Heine S. J. \& Katz, I. M. (1996). "Self-concept clarity: Measurement, personality correlates, and cultural boundaries ”. Journal of Personality and Social Psychology 70 (1996) 141-156.

Cass V. C. (1979). "Homosexuality identity formation: a theoretical model”. Journal of Homosexuality 4 (1979) 219-235.

Coleman E. (1982). “Developmental stages of the coming out process”. Journal of Homosexuality 7 (1982) 31-43.

Ed D., Suh E. M., Lucas R. E. \& Smith H. L. (1999). "Subjective being: Three decades of progress". Psychological Bulletin 125 (1999) 276-302.

DasGupta B. (1992). "Perceived control and examination stress”. Psychology: A Journal of Human Behavior 29 (1992) 31-34.

De Cremer D. \& Sedikides C. (2005). "Self-uncertainty and responsiveness to procedural justice". Journal of Experimental Social Psychology 41 (2005) 157-173.

Ertan C. (2009). Türkiye’de Erkeklik İmgesi ve Eşcinsel Kimliği. Yüksek Lisans Tezi. Akdeniz Üniversitesi SBE. Antalya 2009.

Feinstein B. A., Meuwly N., Davila J., Eaton N. R. \& Yoneda A. (2014). "Sexual orientation prototypicality and well-being among heterosexual and sexual minority adults"'. Archives of Sexual Behavior 44 (2014) 1415-1422. doi:10.1007/s10508-014-0401-4

George D. \& Mallery P. (2010). SPSS for Windows step by step. A simple study guide and reference, (10. Bask1). GEN, Boston, MA: Pearson Education, Inc.

Herek G. M., Gillis J. R. \& Cogan J. C. (2009). "Internalized stigma among sexual minority adults: Insights from a social psychological perspective”. Journal of Counseling Psychology 56 (2009) 32.

Heppner P. P. \& Petersen C. H. (1982). "The development and implications of a personal problem solving inventory”. Journal of Counseling Psychology 29 (1982) 66.

Hossain F. \& Ferreira N. (2019). "Impact of Social Context on the Self-Concept of Gay and Lesbian 
Youth: A Systematic Review”. Global Psychiatry 2/1 (2019) 51-78.

Hovardaoglu S. (1997). "Stres belirtileri ile durumsal ve sürekli kaygının yordanması”. Kriz Dergisi 5 (1997) 127135.

Joreskog K. G. \& Sorbom D. (1993). LISREL 8: Structural Equation Modeling with the SIMPLIS Command Language. Scientific Software International Lawrence Erlbaum Associates, Inc. 1993.

Kaufman, M., Canadian Paediatric Society \& Adolescent Health Committee. (2008). Adolescent sexual orientation. Paediatrics \& Child Health, 13(7), 619-623.

Kernis M. H., Paradise A. W., Whitaker D. J., Wheatman S. R. \& Goldman B. N. (2000). "Master of one's psychological domain? Not likely if one's self-esteem is unstable”. Personality and Social Psychology Bulletin 26 (2000) 1297-1305.

Kishton J. M. \& Widaman K. F. (1994). "Unidimensional versus domain representative parceling of questionnaire items: An empirical example”. Educational and Psychological Measurement 54 (1994) 757-765.

Lackner J. B., Joseph J. G., Ostrow D. G. \& Eshleman S. (1993). “The effects of social support on Hopkins Symptom Checklist-assessed depression and distress in a cohort of human immunodeficiency virus-positive and negative gay men". Journal of Nervous and Mental Disease 181 (1993) 632- 638.

Lee-Flynn S. C., Pomaki G., DeLongis A., Biesanz J. C. \& Puterman E. (2011). "Daily cognitive appraisals, daily affect, and long-term depressive symptoms: The role of self-esteem and self concept clarity in the stress process”. Personality and Social Psychology Bulletin 37 (2011) 255268.

Leite C. \& Kuiper N. A. (2008). "Client uncertainty and the process of change psychotherapy: The impact of individual differences in self concept clarity and intolerance of uncertainty". Journal of Contemporary Psychotherapy 38 (2008) 55-64.

Luyckx K., Schwartz S. J., Goossens L. \& Pollock S. (2008). "Employment, sense of coherence, and identity formation: Contextual and psychological processes on the pathway to sense of adulthood". Journal of Adolescent Research 23 (2008) 566-591.

MacCallum R. C. \& Austin J. T. (2000). “Applications of structural equation modeling in psychological research”. Annual Review of Psychology 51 (2000) 201-226.

Meyer IH (2003) "Prejudice, Social Stress, and Mental Health in Lesbian, Gay, and Bisexual Populations: Conceptual Issues and Research Evidence”. Psychol Bull 129/5 (2003) 674- 697.

Meyer I. H. \& Frost D. M. (2013). "Minority stress and the health of sexual minorities". Eds. C. J. Patterson \& A. R. D’Augelli, Handbook of psychology and sexual orientation. New York (2013) 252-266.

Moradi B., Wiseman M. C., DeBlaere C., Goodman M. B., Sarkees A., Brewster M. E., \& Huang Y. $\quad$ P. (2010). "LGB of color and white individuals' perceptions of heterosexist stigma, internalized homophobia, and outness: Comparisons of levels and links”. The Counseling Psychologist 38 (2010) 397-424.

Newman BS. \& Muzzonigro PG. (1993). "The effect of traditional family values on the out process of gay male adolescents”. United States 28 (1993) 213-26.

Nisbett R. E. \& Wilson T. D. (1977). "Telling more than we can know: verbal reports on mental processes”. Psychological Review 84 (1977) 231- 259.

Öztürk, E. (1998). “Kadın ve Erkeklerde Eşcinsellik: Boylamsal Bir Çalışma”. X. Ulusal Psikoloji Kongresi (16-18 Eylül 1998). Ankara 1998.

Öztürk E. (1994). Erkek Eşcinsellerde Anksiyete ve Depresyon Düzeylerinin Değerlendirilmesi. Yüksek Lisans Tezi. İstanbul Üniversitesi. Sosyal Bilimler Enstitüsü. İstanbul 1994.

Page M. J., Lindahl K. M. \& Malik N. M. (2013). "The role of religion and stress in sexual identity and mental health among lesbian, gay, and bisexual youth". Journal of Research on Adolescence 23 (2013) 665-677.

Plummer K. (1995). Telling Sexual Stories: Power, Change and Social Worlds. London 1995.

Poteat V. P., Aragon S. R., Espelage D. L. \& Koenig B. W. (2009). "Psychosocial concerns of sexual 
minority youth: Complexity and caution in group differences". Journal of Consulting and Clinical Psychology 77 (2009) 196.

Prochaska J. O. \& DiClemente C. C. (1983). "Stages and processes of self-change of smoking: toward an integrative model of change". Journal of Consulting and Clinical Psychology 51(1983) 390.

Ojanen, T. T. (2015). "Online Counseling Services for LGBTI People in Thailand: rationale, realization, and research". In BUU \& AMSAR 2015 International Conference: Communication Perspective: Social Connection in the Age of Digital Technology Practice. (2015) 14-24.

Reyes M. E. S., Lanic P. J. P., Lavadia E. N. T., Tactay E. F. J. L., Tiongson E. R., Tuazon P. J. G. \& McCutcheon L. E. (2015). "Self-stigma, self-concept clarity, and mental health status of Filipino LGBT individuals". North American Journal of Psychology 17/2 (2015) 343-350.

Ritchie T. D., Sedikides C., Wildschut T., Arndt J. \& Gidron Y. (2011). "Self-concept clarity mediates the relation between stress and subjective well-being". Self and Identity 10 (2011) 493-508.

Rosario M., Schrimshaw E. W. \& Hunter J. (2004). "Ethnic/racial differences in the coming-out process of lesbian, gay, and bisexual youths: A comparison of sexual identity development over time". Cultural Diversity and Ethnic Minority Psychology 10 (2004) 215.

Russell S. T., Ryan C., Toomey R. B., Diaz, R. M. \& Sanchez J. (2011). "Lesbian, gay, bisexual, and transgender adolescent school victimization: Implications for young adult health and adjustment". Journal of School Health 81 (2011) 223-230.

Ryan C., Huebner D., Diaz R. M. \& Sanchez J. (2009). "Family rejection as a predictor of negative health outcomes in white and Latino lesbian, gay, and bisexual young adults". Pediatrics 123 (2009) 346-352.

Şahin N., Şahin N. H. \& Heppner P. P. (1993). "Psychometric properties of the problem solving inventory in a group of Turkish university students". Cognitive Therapy and Research17 (1993) 379-396.

Şimşek O. F. (2013). "Self-absorption paradox is not paradox: Illuminating the dark side of self reflection". International Journal of Psychology 48 (2013) 1109-1121.

Şimşek O. F., Ceylandag A. E. \& Akcan G. (2013). "The need for absolute truth and self-rumination as basic suppressors in the relationship between private self-consciousness and mental health". The Journal of General Psychology 140 (2013) 294-310.

Slotter E. B., Gardner W. L. \& Finkel E. J. (2010). "Who am I without you? The influence of romantic breakup on the self-concept". Personality and Social Psychology Bulletin 36 (2010) 147-160.

Smith M., Wethington E. \& Zhan, G. (1996). "Self-concept clarity and preferred coping styles". Journal of Personality 64 (1996) 407-434.

Sumer N. \& Gungor D. (1999). "Yetişkin bağlanma stilleri ölçeklerinin Türk örneklemi üzerinde psikometrik değerlendirmesi ve kültürlerarası bir karşılaştırma ". Türk Psikoloji Dergisi 14 (1999) 71106.

Swann W. B., Pelham B. W. \& Chidester T. R. (1988). "Change through paradox: Using self verification to alter beliefs". Journal of Personality and Social Psychology 54 (1988) 268. ISO 690.

Szymanski D. M. \& Gupta A. (2009). "Examining the relationship between multiple internalized oppressions and African American lesbian, gay, bisexual, and questioning persons' self-esteem and psychological distress". Journal of Counseling Psychology 56 (2009) 110.

Troiden R. R. (1989). "The formation of homosexual identities”. Journal of Homosexuality 17 (2009) 43-73.

Uluyol F. M. (2016). "Cinsiyet kimliği ve cinsel yönelime bağlı zorbalığa maruz kalma, sosyal destekve psikolojik iyilik hali arasındaki ilişki”. Klinik Psikiyatri Dergisi 19/2 (2016) 87-96.

Watkins E. R. (2008). "Constructive and unconstructive repetitive thought". Psychological Bulletin 134 (2008) 163-206.

Watkins, E. \&Teasdale J. D. (2004). "Adaptive and Maladaptive Self-Focus in Depression”. Journal of Affective Disorders 82 (2004) 1-8.

Wegner D. M., \& Lane J. D. (1995). "From secrecy to psychopathology". Ed. J. W. Pennebaker, Emotion, Disclosure, \& Health.. American Psychological Association. (1995) 25-46. https://doi.org/10.1037/10182-002. 